JURNAL RESPIRASI

Vol. 1 No. 2 Mei 2015

\title{
Hubungan Kadar Interleukin-10 dan Tuberkulosis Multi-Drug Resistant
}

Nurjanah Lihawa, Resti Yudhawati

Departemen Pulmonologi dan Ilmu Kedokteran Respirasi, Fakultas Kedokteran Universitas Airlangga/RSUD Dr Soetomo

\begin{abstract}
Background: Prevalence of multi-drug resistant tuberculosis (MDR-TB) is increased by the time. In Indonesia, there were an estimated $1.9 \%$ of new cases and $12 \%$ of previously treated cases. Protection against Mycobacterium tuberculosis is dependent on Th1 cell $C D 4^{+}$that produced pro-inflammatory cytokines such as IFN- $\gamma$ and TNF- $\alpha$. T cell regulators (Tregs) produced IL-10 as antiinflammatory cytokine is against the function of those pro-inflammatory cytokines. It is believed that immune suppression is responsible for MDR-TB. The previous study showed impaired Th1 responses and enhanced regulatory T-cell levels in circulatory blood of MDRTB patients. The study of IL-10 represented anti-inflammation cytokine as immune suppression never been conducted in Indonesia. Objective: To analyze relationship between level of interleukin-10 and Multi-drug resistant tuberculosis. Methods: The study was conducted at the outpatient department of MDR-TB and DOTS of Dr. Soetomo hospital in Surabaya. Total sample was 38 of TB patients that consist of 19 MDR-TB patients (secondary resistant) and 19 non-MDR TB patients as control. Results: In this study we found that the median level of $I L-10$ as $5.7 \pm 3.3 \mathrm{pg} / \mathrm{mL}$ in the group of MDR-TB patients with minimum level was $1.3 \mathrm{pg} / \mathrm{mL}$ and maximum level was $14.0 \mathrm{pg} / \mathrm{mL}$ while median level of $\mathrm{LL}-10$ in non-MDR TB patients was $7.0 \pm 3.4 \mathrm{pg} / \mathrm{mL}$ with $3.2 \mathrm{pg} / \mathrm{mL}$ and $16.5 \mathrm{pg} / \mathrm{mL}$, respectively. To analyze correlation between time to first of having TB until became MDR-TB and level of IL-10 by using Pearson's correlation, we showed that no statistical correlation ( $p>0.05$ ). According to statistical classification, we found that no statistical correlation between level of IL-10 and the history of treatment in MDR-TB patients $(p>0.05)$. Data showed that all the history of treatment classification dominated by MDR-TB patients with the low level of IL-10. We also found that no statistical difference with the level of IL-10 in MDR$T B$ and non-MDR TB patients ( $p>0.05$ ) although in descriptive state we found the level of IL-10 was higher in non-MDR TB patients. And also there was no relationship between level of IL-10 and MDR-TB ( $p>0.05)$. It could be explained that the host factor was not involved and in the other side we still not known the factor of agents, yet. The low level of IL-10 that was observed in this study could be interfering by the strain of M.tb which not assessed in this study. Conclusion: In this study we found that level of IL-10 is not increase in MDR-TB patients and there was no relationship between level of IL-10 and MDR-TB $(p>0.05)$.
\end{abstract}

Key words: MDR-TB, anti-inflammation cytokines, IL-10

\section{PENDAHULUAN}

Tuberkulosis (TB) adalah penyakit menular yang disebabkan oleh infeksi Mycobacterium tuberculosis (M.tb). Diperkirakan sekitar sepertiga penduduk dunia saat ini telah terinfeksi oleh M.tb tersebut. Tuberkulosis paru masih merupakan masalah kesehatan yang penting di dunia oleh karena penyakit ini menyerang berjuta penduduk dan menjadi peringkat kedua penyebab kematian di antara penyakit infeksi, setelah Human Immunodeficiency Virus (HIV). Secara global terdapat 9 juta kasus baru pada tahun 2011 dan 1.4 juta kematian oleh karena TB. WHO menyebutkan dari 22 negara dengan beban tinggi akan masalah TB (high burden country), Indonesia menduduki peringkat keempat (setelah India, China, dan Afrika Selatan) dengan prevalensi TB sebesar 289 per 100.000 penduduk, insidensi TB sebesar 189 per 100.000 penduduk, dan angka kematian sebesar 27 per 100.000 penduduk. ${ }^{1}$

Multi-drug resistant tuberculosis (TB-MDR) didefinisikan sebagai resistensi in vitro terhadap isoniazid $(H)$ dan rifampisin $(R) .{ }^{2}$ Di Indonesia didefinisikan sebagai resistensi terhadap, sekurang-kurangnya $H$ dan $R$ secara bersamaan, dengan atau tanpa resistensi terhadap obat anti tuberkulosis (OAT) lini pertama yang lain. ${ }^{3}$ Data dari WHO menunjukkan prevalensinya semakin meningkat dari tahun ke tahun. Di seluruh dunia diperkirakan terdapat 3.7\% TB-MDR kasus baru dan 20\% TB-MDR dengan riwayat pengobatan OAT sebelumnya, di Indonesia angka-angka 
tersebut adalah $1.9 \%$ dan $12 \%$. Keadaan tersebut pada akhirnya akan menyebabkan terjadinya epidemi TB yang sulit ditangani dan dengan mortalitas yang tinggi. Oleh karena itu maka perhatian penuh diarahkan untuk penemuan cara diagnostik terbaru, obat-obatan terbaru, dan juga vaksin terbaru yang dapat menangkal TB sebelum infeksi ini menjadi tidak terkendali. ${ }^{1,4}$

Secara statistik, dari populasi yang terinfeksi tuberkulosis, hanya sekitar $5-10 \%$ yang kemudian berkembang menjadi tuberkulosis aktif dengan berbagai manifestasinya. Hal ini disebabkan karena adanya keseimbangan mekanisme pertahanan tubuh pejamu dan bakteri. ${ }^{5}$ Seperti yang telah diketahui bahwa lesi TB utamanya terdiri dari sel-sel imun, maka derajat kerusakan jaringan ataupun perjalanan penyakitnya merupakan refleksi dari kemampuan pejamu untuk membangun pertahanan respons imun terhadap antigen TB, di mana hal ini dapat dilihat dengan mendeteksi sitokin-sitokin seperti interferon- $\gamma$ (IFN- $\gamma$ ), tumor necrosis factor- $\alpha$ (TNF- $\alpha$ ), dan interleukin-10 (IL-10). IFN- $\gamma$ diproduksi oleh sel Cluster of Differentiation $4\left(\mathrm{CD}^{+}\right)$Th1 berperan sebagai sitokin utama yang melawan infeksi M.tb. Sedangkan peranan TNF- $\alpha$ dan IL-10 saling bertentangan selama infeksi M.tb, di mana TNF- $\alpha$ berperan mempertahankan fungsi tuberkulostatik makrofag sedangkan IL-10 berperan menekan fungsi makrofag sehingga efek mikobakterisidal tertekan dan M.tb dapat memperbanyak diri dan bila terjadi overload dari bakteri memungkinkan terjadinya mutasi spontan di mana M.tb membentuk kekebalan terhadap obat antituberkulosis. ${ }^{4,6}$

Teori tentang timbulnya TB-MDR resistensi sekunder (resistensi yang timbul setelah pasien meminum obat), terutama disebabkan oleh fenomena buatan manusia (manmade phenomenon) telah banyak dibahas pada berbagai kepustakaan dan pada umumnya disebabkan oleh pemberian regimen pengobatan yang tidak akurat seperti pengobatan TB yang tidak adekuat dan rendahnya kepatuhan berobat pasien, secara selektif akan menyebabkan multiplikasi mutan M.tb kebal obat di antara basil yang masih sensitif di dalam lesi TB. Selama masa pengobatan terdapat tiga mekanisme yang memungkinkan terjadinya seleksi strain mutan kebal-obat yaitu: terapi obat efektif dengan jumlah yang tidak adekuat, dosis sub-terapeutik atau adanya malabsorbsi, ataupun penghentian terapi (secara sepihak oleh pasien/default). ${ }^{78}$ Di lain pihak penyebab timbulnya TB-MDR oleh karena faktor pejamu (host) dan faktor kuman (agent) masih belum banyak dibahas.

Timbulnya imunsupresi berdasarkan beberapa kepustakaan dapat merupakan faktor terjadinya TB-MDR. Beberapa peneliti menemukan terganggunya produksi sitokin Th1 termasuk TNF- $\alpha$, IL-1 dan IL-12 pada darah tepi pasien-pasien TB-MDR ini. ${ }^{9}$ Penelitian oleh Geffner dkk memperlihatkan peranan sel Th1, yang merupakan pola respons imun utama melawan M.tb, terganggu dan terdapat peningkatan respons Tregulator (Treg) yang bersifat kontra terhadap sel Th1, ditemukan pada pasien TB-MDR dibandingkan dengan TB non-MDR. Dan pada penelitian Skolimowska dkk menyimpulkan keadaan ini dapat disebabkan oleh besarnya bacterial load pada pasien TB-MDR. $^{10,11}$ Diketahui bahwa sel Treg memproduksi IL-10, penelitian mengenai peranan IL-10 seperti yang dilakukan oleh O'Leary dkk dilakukan secara in vitro ditemukan bahwa IL-10 dapat menghambat pematangan fagosom dalam makrofag sehingga dengan menghalangi produksi IL-10 dapat merupakan imunoterapi tambahan pada terapi TB-MDR konvensional. Juga pada penelitian oleh Lee dkk memperlihatkan dengan menetralkan IL-10 akan meningkatkan produksi TNF- $\alpha$ dan bersama-sama dengan IFN- $\gamma$ akan meningkatkan kemampuan makrofag untuk mengeradikasi M.tb. ${ }^{12,13}$

Dengan adanya fakta bahwa faktor imunitas pejamu berperan terhadap terjadinya TB-MDR (resistensi sekunder) maka kami mencoba untuk melihat pada penelitian ini apakah ada hubungan pengaruh imunsupresi dalam hal ini diwakili oleh IL-10 pada pasien TB-MDR, dan juga oleh karena penelitian yang ada sebelumnya kebanyakan dilakukan pada hewan coba ataupun secara in vitro, serta penelitian ini belum pernah dilakukan di Indonesia sebelumnya.

\section{METODE}

Penelitian ini bersifat analitik observasional dengan menggunakan pendekatan cross sectional. Pengambilan sampel yang dilakukan dengan cara consecutive sampling. Sampel dalam penelitian ini adalah Pasien TB-MDR (resistensi sekunder) yang berobat di poli TB-MDR dan pasien TB non-MDR yang berobat di poli DOTS RSUD Dr. Soetomo Surabaya yang memenuhi kriteria inklusi dan ekslusi. Berdasarkan perhitungan rumus diperoleh 38 pasien sebagai sampel. Kriteria inklusi dalam penelitian ini adalah pasien berumur 15-65 tahun, berjenis kelamin laki dan perempuan, pasien TB-MDR (resistensi sekunder), pasien TB non-MDR serta bersedia menandatangani inform consent, sedangkan kriteria eksklusi dalam penelitian ini adalah pasien yang menderita HIV-AIDS, penyakit keganasan dan penyakit paru kronis lainnya seperti asma dan PPOK serta pasien yang mendapat pengobatan imunosupresan.

Instrumen penelitian yang digunakan dalam penelitian ini adalah kuisioner berisi data dasar identitas pasien dan daftar pertanyaan, spoit $5 \mathrm{cc}$, venoject $5 \mathrm{cc}$, dan kapas alcohol dan prosedur penelitian yang dilakukan meliputi:

(1) wawancara dengan mengisi formulir data dasar subjek penelitian seperti identitas pasien, anamnesis tentang riwayat penyakit sekarang meliputi gejala TB paru seperti batuk, berdahak selama 2-3 minggu atau lebih, dahak bercampur darah, sesak napas, nyeri dada, badan lemas, nafsu makan menurun, berat badan menurun, berkeringat malam hari tanpa kegiatan fisik, dan demam. uga anamnesis mengenai gejala dari Asma, Penyakit Paru Obstruktif Kronis (PPOK), penyakit keganasan dan faktor risiko HIV/AIDS. Pemeriksaan fisik meliputi pemeriksaan 
umum, pengukuran berat badan, tinggi badan, tensi, nadi, dan frekuensi napas. (2) Pemeriksaan fisik juga ditujukan untuk mencari adanya tanda-tanda keganasan dan HIV/ AIDS yang lebih khusus,juga dicatat hasil Gene-Xpert dan hasil uji kepekaan OAT lini pertama (pada pasien TB-MDR resistensi sekunder) serta hasil pemeriksaan sputum BTA (pada pasien TB non-MDR) sebelum terapi. (3) Pemeriksaan kadar IL-10; darah vena diambil dengan jarum suntik sebanyak $5 \mathrm{cc}$, kemudian dilakukan sentrifus selama beberapa menit. Serum yang dihasilkan diambil, kemudian dimasukan kedalam tabung dan simpan dalam lemari pendingin dengan suhu $-70^{\circ} \mathrm{C}$. Pengukuran kadar IL-10 dilakukan dengan cara ELISA, yaitu menambahkan $200 \mu \mathrm{g}$ reagen $\mathrm{IL}-10$ ke dalam $50 \mu \mathrm{g}$ serum penderita.

Data yang diperoleh dicatat dan dikumpulkan kemudian diolah dengan komputer memakai software SPSS 13. Analisa data dilakukan dengan independent sample $t$ test untuk melihat perbandingan kadar IL-10 pada TB-MDR dan TB non-MDR apabila sebaran data normal dan digunakan uji Mann-Whitney apabila sebaran data tidak normal. Uji regresi logistik digunakan untuk melihat hubungan antara IL-10 dan TB-MDR.

\section{HASIL}

Penelitian ini adalah dilakukan terhadap 38 pasien TB di RSUD Dr. Soetomo Surabaya dan terbagi menjadi 2 kelompok yaitu pasien TB-MDR dan pasien TB nonMDR. Subjek pasien didominasi oleh pria yaitu TB-MDR sebanyak 12 (63,2\%) pasien dan TB non-MDR sebanyak13 $(68,4 \%)$ pasien. Rerata umur subjek pasien TB-MDR adalah 43,2 tahun $\pm 9,0$, dengan umur minimum 31 tahun dan umur maksimum 57 tahun, sedangkan rerata umur subjek pasien TB non-MDR adalah 39,5 tahun $\pm 12,2$, dengan umur minimum 21 tahun dan umur maksimum 65 tahun. Dari karakteristik subjek pasien TB berdasarkan pengukuran IL-10 didapatkan rerata IL-10 pada subjek pasien TB-MDR adalah 5,7 pg/mL, dengan nilai minimum 1,3 pg/mL dan nilai maksimum $14,0 \mathrm{pg} / \mathrm{mL}$. Sedangkan rerata IL-10 pada subjek pasien TB non-MDR adalah 7,0 pg/mL, dengan nilai minimum 3,2 pg/mL dan nilai maksimum 16,5 pg/ $\mathrm{mL}$. Kisaran interkuartil pada subjek pasien TB-MDR adalah 3,8 pg/mL, sedangkan kisaran interkuartil pada subjek pasien TB non-MDR adalah 4,8 pg/mL. Angka ini menunjukkan kadar IL-10 lebih menyebar pada subjek pasien TB non-MDR dengan selisih 1,0 pg/mL.Kisaran interkuartil pada subjek pasien TB-MDR adalah 3,8 pg/ $\mathrm{mL}$, sedangkan kisaran interkuartil pada subjek pasien TB non-MDR adalah 4,8 pg/mL. Angka ini menunjukkan kadar IL-10 lebih menyebar pada subjek pasien TB non-MDR dengan selisih $1,0 \mathrm{pg} / \mathrm{mL}$.

Hasil uji normalitas menunjukkan bahwa data waktu yang diketahui sejak pertama subjek pasien menderita TB sampai menjadi TB MDR dan IL-10 berdistribusi normal, dengan tingkat signifikansi $>0,05$ sedangkan hasil korelasi pearson antara waktu sejak pertama subjek pasien menderita TB sampai menjadi TB-MDR dengan IL-10 didapatkan koefisien korelasi sebesar -0,142 dengan tingkat signifikansi 0,574 . Ini berarti tidak ada hubungan yang bermakna antara waktu sejak pertama subjek pasien menderita TB sampai menjadi TB-MDR dengan kadar IL-10.

Hasil tabulasi silang (crosstab) antara riwayat pengobatan subjek pasien TB-MDR dengan kategori IL-10 dapat dilihat pada tabel 1 yaitu tabulasi silang antara riwayat pengobatan subjek pasien TB-MDR dengan kategori IL-10 menghasilkan Chi-Square sebesar 2,243 dengan tingkat signifikansi 0,691 . Ini berarti tidak ada hubungan yang bermakna antara riwayat pengobatan subjek pasien TB-MDR dengan kategori IL-10. Dapat dilihat bahwa 7 $(58,3 \%)$ pasien yang memiliki riwayat pengobatan gagal mempunyai $\mathrm{IL}-10$ tergolong rendah, 2 (50\%) pasien yang memiliki riwayat pengobatan relaps mempunyai IL-10 tergolong rendah, dan 3 (100\%) pasien yang memiliki riwayat pengobatan lainnya mempunyai IL-10 tergolong rendah. Semua klasifikasi pasien TB-MDR berdasarkan riwayat pengobatan didominasi dengan pasien yang memiliki kadar IL-10 rendah.

Hasil uji normalitas data IL-10 dapat dilihat pada tabel 2 yaitu bahwa data IL-10 pada subjek pasien TB-MDR maupun TB non-MDR berdistribusi normal, dengan tingkat signifikansi $>0,05$.

Hasil independent sample t-testantara IL-10 subjek pasien TB-MDR dan TB non-MDR dapat dilihat pada tabel 3 diketahui independent sample t-testdengan equal variances assumed (tingkat signifikansi levene test> $0,05)$ menghasilkan nilai t sebesar $-1,180$ dengan tingkat signifikansi sebesar 0,246 . Ini berarti tidak terdapat perbedaan bermakna antara IL-10 subjek pasien TB-MDR dan TB non-MDR.

Tabel 1. Tabulasi Silang Antara Riwayat Pengobatan Subjek Pasien TB-MDR dengan Kategori IL-10

\begin{tabular}{|c|c|c|c|c|c|c|}
\hline \multirow{7}{*}{$\begin{array}{l}\text { Riwayat } \\
\text { Pengobatan }\end{array}$} & \multirow{3}{*}{ Gagal } & \multicolumn{4}{|c|}{ Kategori IL-10 } & Rendah Sedang Tinggi Total \\
\hline & & $\mathrm{F}$ & 7 & 3 & 2 & 12 \\
\hline & & $\%$ & 58,3 & 25,0 & 16,7 & 100,0 \\
\hline & \multirow[t]{2}{*}{ Relaps } & $\mathrm{F}$ & 2 & 1 & 1 & 4 \\
\hline & & $\%$ & 50,0 & 25,0 & 25,0 & 100,0 \\
\hline & \multirow{2}{*}{$\begin{array}{l}\text { Riwayat } \\
\text { pengobatan } \\
\text { lainnya }\end{array}$} & $F$ & 3 & 0 & 0 & 3 \\
\hline & & $\%$ & 100,0 & 0,0 & 0,0 & 100,0 \\
\hline \multirow{2}{*}{\multicolumn{2}{|c|}{ Total }} & $\mathrm{F}$ & 12 & 4 & 3 & 19 \\
\hline & & $\%$ & 63,2 & 21,1 & 15,8 & 100,0 \\
\hline
\end{tabular}

Chi-Square = 2,243; Sig.= 0,691

Tabel 2. Uji Normalitas Data IL-10

\begin{tabular}{lccc}
\hline \multicolumn{1}{c}{ IL-10 } & Kolmogorov & Sig. & Keterangan \\
TB-MDR & 1,065 & 0,206 & Normal \\
TB non-MDR & 0,914 & 0,374 & Normal \\
\hline
\end{tabular}


Tabel 3. Independent Sample T-TestlL-10 Subjek Pasien TBMDR dan TB non-MDR

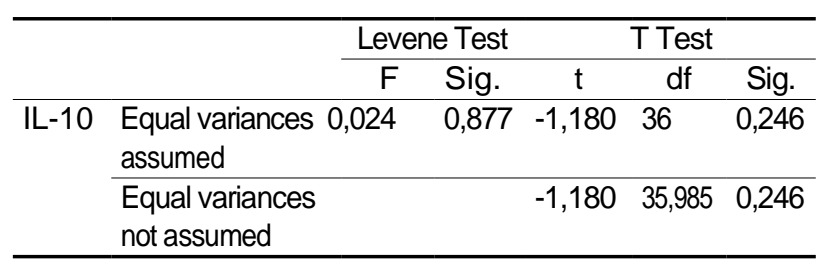

Tabel 4. Logistic Regression KadarlL-10 Terhadap Kelompok Subjek Pasien TB

\begin{tabular}{ccccccc}
\hline & \multicolumn{2}{c}{$\begin{array}{c}\text { Hosmer and } \\
\text { Lemeshow Test }\end{array}$} & \multicolumn{4}{c}{ Wald Test } \\
\cline { 2 - 7 } & Chi-Square & Sig. & B & Wald & Sig. & Exp (B) \\
\hline IL-10 & 10,436 & 0,165 & 0,122 & 1,351 & 0,245 & 1,130 \\
\hline
\end{tabular}

Hasil logistic regression kadar IL-10 terhadap kelompok subjek pasien TB akan dijelaskan pada tabel 4 diketahui hosmer and lemeshow test menghasilkan nilai chi-square sebesar 10,436 dengan tingkat signifikansi 0,165 yang menunjukkan bahwa model logistic regression yang digunakan dalam penelitian ini layak untuk dianalisis lebih lanjut. Wald test menghasilkan nilai statistik sebesar 1,351 dengan tingkat signifikansi sebesar 0,245 . Ini berarti tidak ada pengaruh yang bermakna kadar IL-10 terhadap kelompok subjek pasien TB. Pasien dengan kadar IL-10 yang lebih tinggi, tidak mempunyai peluang yang lebih tinggi menjadi kelompok pasien TB non-MDR. Dengan kata lain, pasien dengan kadar IL-10 tinggi bisa digolongkan ke dalam kelompok TB-MDR. Hasil ini juga menyimpulkan bahwa tidak ada hubungan antara kadar IL-10 dengan kelompok pasien TB-MDR dan TB non-MDR.

\section{PEMBAHASAN}

Penelitian ini melibatkan subjek sebanyak 38 orang pasien TB yang terbagi dalam dua kelompok yaitu masingmasing sebanyak 19 pasien TB-MDR dan 19 pasien TB nonMDR yang berobat di RSUD Dr. Soetomo. Karakteristik pasien berdasarkan jenis kelamin pada kelompok pasien TB-MDR dan TB non-MDR didominasi oleh pria masingmasing 12 (63,2\%) pasien dan $13(68,4 \%)$ pasien. Hal ini sesuai dengan data epidemiologi WHO tahun 2011 di Indonesia di mana perbandingan antara pria dan wanita yaitu 1,5:1. ${ }^{1}$ Angka kejadian TB lebih tinggi pada laki-laki dibanding perempuan diduga akibat perbedaan pajanan dan risiko infeksi. Perbedaan tersebut kemungkinan disebabkan karena laki-laki dewasa lebih sering melakukan aktivitas sosial di luar rumah. Dan juga terdapat perbedaan perilaku dalam mencari perawatan kesehatan antara laki-laki dan perempuan sehingga lebih banyak kasus TB pada laki-laki yang dilaporkan. ${ }^{51}$
Karakteristik pasien berdasarkan umur terlihat rerata umur subjek pasien TB-MDR adalah 43,2 tahun, dengan umur minimum 31 tahun dan umur maksimum 57 tahun, sedangkan rerata umur subjek pasien TB non-MDR adalah 39,5 tahun, dengan umur minimum 21 tahun dan umur maksimum 65 tahun.Data ini sesuai dengan laporan WHO yang menyebutkan bahwa penyakit TB terutama menyerang kelompok usia produktif dengan tiga perempat dari kasus berusia antara 15-49 tahun. $^{1}$

Oleh karena kedatangan pasien mencari pengobatan berbeda-beda setelah onset penyakit, sehingga Eum dkk mengasumsikan bahwa pasien akan berada pada status immunokompetens yang berbeda-beda pula pada saat pemeriksaan oleh klinisi, tanpa menghubungkan dengan luasnya penyakit secara radiologis dan mikrobiologis. ${ }^{4}$ Chiacchio dkk melihat bahwa respons Th2 terlihat muncul pada saat stadium lanjut penyakit TB yang ditandai dengan peningkatan produksi IL-4 dan IL-10 dan ekspansi dari Treg. ${ }^{52}$ Sementara Sahiratmadja menyimpulkan pula bahwa lamanya perjalanan penyakit dapat mempengaruhi keadaan imunitas pasien. ${ }^{53}$ Sehingga pada penelitian ini kami mencoba mencari hubungan antara waktu sejak pertama subjek menderita TB hingga menjadi TB-MDR dan kadar IL-10 dengan hasil tidak ada hubungan yang bermakna. Kemungkinan hal ini dapat terjadi oleh karena keterbatasan dalam jumlah sampel pada penelitian ini, di mana pada penelitian-penelitian tersebut diatas melibatkan subjek dalam jumlah besar.

Kami mengklasifikasikan pasien TB-MDR ini berdasarkan riwayat pengobatan sebelumnya dan melihat apakah ada hubungan antara riwayat pengobatan sebelumnya dengan kategori IL-10 (yang dibuat berdasarkan statistik). Dari 19 subjek penelitian kelompok TB-MDR, pasien terklasifikasi ke dalam kasus pengobatan setelah gagal yaitu pasien yang sebelumnya telah mendapatkan OAT dan dinyatakan gagal pada akhir pengobatan, kasus kambuh yaitu pasien yang sebelumnya telah mendapatkan OAT dan dinyatakan sembuh atau pengobatan lengkap pada akhir pengobatan dan saat ini ditegakkan diagnosis TB episode rekuren (baik untuk kasus yang benar-benar kambuh atau episode baru yang disebabkan reinfeksi) dan kasus dengan riwayat pengobatan lainnya yaitu pasien sebelumnya pernah mendapatkan OAT dan hasil akhir pengobatannya tidak diketahui atau tidak didokumentasikan. ${ }^{3}$ Terlihat bahwa subjek penelitian terbanyak diklasifikasikan ke dalam gagal pengobatan (baik kategori 1 ataupun 2) yaitu sebanyak 12 orang $(63 \%)$. Sisanya diklasifikasikan ke dalam relaps dan riwayat pengobatan lainnya. Hal ini sesuai dengan data epidemiologi di mana klasifikasi pasien TB-MDR berdasarkan riwayat pengobatan sebelumnya didominasi oleh kasus gagal terapi ataupun relaps yang mengambil porsi terbesar. $^{4}$

Apabila dihubungkan antara riwayat pengobatan sebelumnya dengan kategori IL-10 (secara statistik) diperoleh hasil tidak ada hubungan yang bermakna antara riwayat pengobatan pasien TB-MDR dengan kategori IL-10. Terlihat bahwa 7 pasien $(58,3 \%)$ dengan riwayat 
pengobatan gagal mempunyai IL-10 yang tergolong rendah, 2 pasien (50\%) dengan riwayat pengobatan relaps mempunyai IL-10 tergolong rendah, dan 3 pasien (100\%) dengan riwayat pengobatan lainnya mempunyai IL-10 yang tergolong rendah. Semua klasifikasi pasien TB-MDR berdasarkan riwayat pengobatan didominasi oleh pasien yang memiliki kadar IL-10 rendah.

Secara teori diketahui umumnya bahwa infeksi M.tb diasumsikan hanya disebabkan oleh satu strain saja, dan kekambuhan dipercaya sebagai akibat dari reaktivasi oleh strain yang menyebabkan infeksi pertama tadi. ${ }^{54}$ Sementara sangat jarang kita memperkirakan terjadi infeksi oleh strain kuman M.tb secara multipel pada satu pasien baik sebelum, selama ataupun bahkan setelah terapi berhasil dilaksanakan. Penelitian oleh van Rie dkk memperlihatkan dengan menggunakan analisis DNA-fingerprinting terdapat beberapa pasien TB-MDR yang memperlihatkan terjadi infeksi gabungan dari beberapa strain M.tb. ${ }^{55}$

Hasil penelitian ini memperlihatkan proporsi terbanyak dari kelompok pasien TB-MDR adalah dengan riwayat pengobatan gagal terapi. Teori tentang kemungkinan terjadinya infeksi gabungan menjelaskan bahwa terdapat strain kuman kebal-obat yang tidak terdeteksi yang pada akhirnya terlihat setelah diberikan pengobatan OAT lini pertama. Pengobatan tersebut mampu mengeradikasi strain yang masih rentan sehingga akan menyisakan strain yang kebal-obat dan akhirnya pasien akan jatuh ke dalam keadaan gagal terapi. Tetapi keterbatasan dalam penelitian ini adalah tidak diketahuinya strain apa saja yang menyebabkan TB-MDR dan apakah terjadi pula infeksi gabungan pada subjek penelitian ini. Hal ini penting karena diketahui strain M.tb tertentu berperan menginduksi IL-10, sehingga pada penelitian ini tidak didapatkan hubungan antara riwayat pengobatan dengan kategori IL-10 kemungkinan terkait dengan strain tersebut.

Dengan adanya kecenderungan peningkatan insiden TBMDR menyebabkan permasalahan kesehatan masyarakat dan juga masalah dalam pengobatan. Saat ini adanya deviasi imun dipertimbangkan sebagai penyebab utama resistensi pada TB-MDR. Walaupun demikian, mekanisme sesungguhnya tentang terjadinya TB-MDR masih membutuhkan penelitian lebih lanjut. Telah diketahui bahwa imunitas protektif terhadap mikroba intraseluler secara predominan sangat tergantung pada pelepasan sel T sitokin seperti IL-12 dan IFN- $\gamma$ yang mengaktifkan makrofag dan mengeradikasi mikobakterium intraseluler. ${ }^{56}$ Beberapa penelitian memperlihatkan secara keseluruhan respons imun menurun pada pasien TB-MDR. ${ }^{9,10,57,58}$

Sitokin IL-10 digolongkan ke dalam kelompok sitokin Th2 dengan efek anti-inflamasi dan berperan dalam menghambat fungsi makrofag dengan cara menghalangi produksi IL-12 dan akibatnya menurunkan produksi IFN- $\gamma$ oleh limfosit T. ${ }^{59}$ Beberapa penelitian menyebutkan bahwa pada pasien TB non-MDR sebelum pengobatan didapatkan kadar IL-10 yang tinggi dan kadarnya menurun pada saat dan setelah pengobatan. ${ }^{38,47,60,61}$ Tetapi penelitian mengenai IL-10 pada pasien TB-MDR masih bersifat kontradiktif satu dengan yang lainnya, pada penelitian oleh Pinheiro dkk didapatkan peningkatan jumlah sel Treg dan IL-10 pada TB-MDR dibandingkan dengan kelompok TB non-MDR dan non tuberkulosis mikobakterium. ${ }^{62}$ Penelitian lainnya menyebutkan IL-10 meningkat secara signifikan pada pasien TB-MDR dan pada TB non-MDR bila dibandingkan dengan kontak. ${ }^{63}$ Pada penelitian ini nilai IL-10 didapatkan tinggi pada pasien TB non-MDR dibandingkan pada pasien TB-MDR walaupun nilai ini secara statistik tidak bermakna. Hasil yang berbeda didapatkan pada penelitian yang dilakukan oleh Shekar-Abi yang menemukan bahwa produksi IL-10 secara signifikan menurun pada TB-MDR bila dibandingkan dengan kontrol pada orang sehat. ${ }^{64}$ Eum dkk menemukan produksi IL-10 yang sedikit lebih tinggi pada TB-MDR dibanding TB non-MDR walaupun juga secara statistik juga tidak bermakna. ${ }^{4}$

Dari hasil penelitian ini tampaknya respons imun supresif Treg yang diwakili oleh pemeriksaan IL-10 tidak terbukti meningkat pada pasien TB-MDR dan hal ini bertolak belakang dengan penelitian sebelumnya. Kemungkinannya adalah bahwa strain yang berbeda pada penelitian ini dibandingkan penelitian yang dilakukan di luar negeri. Seperti yang diketahui bahwa walaupun strain di wilayah Asia didominasi oleh strain Beijing tetapi strain EAI (East-African-Indian) ditemukan dominan di wilayah Asia Tenggara. ${ }^{65}$ Dari penelitian oleh Rocha-Ramirez dkk menyimpulkan strain Beijing akan meningkatkan produksi IL-10, bila dibandingkan strain lain yang kurang virulen. Penelitian ini memperlihatkan bahwa strain M.tb dapat memegang peranan dalam menentukan produksi dan keterlibatan biologis dari IL-10.66 Sehingga yang menjadi kekurangan dalam penelitian ini adalah tidak diketahuinya strain M.tb yang menginfeksi subjek penelitian, diharapkan penelitian selanjutnya dapat dikembangkan dengan mengidentifikasi strain kuman.

Dari hasil analisa yang mencari hubungan antara nilai IL-10 dan TB-MDR pada penelitian ini ditemukan bahwa tidak ada hubungan yang bermakna antara kadar IL-10 dan kelompok pasien TB-MDR maupun TB nonMDR. Pasien dengan kadar IL-10 yang lebih tinggi, tidak mempunyai peluang yang lebih tinggi menjadi kelompok pasien TB non-MDR. Dengan kata lain, pasien dengan kadar IL-10 tinggi bisa digolongkan ke dalam kelompok TB-MDR. Penemuan ini sejalan dengan penelitian yang telah dilakukan oleh Lee dkk di mana kadar IL-10 yang tinggi ditemukan pada pasien-pasien TB-MDR dan TB non-MDR. ${ }^{63}$

Kemungkinan hal ini dapat disebabkan oleh sel-sel imun lokal repiratori dapat bereaksi berbeda terhadap mikroba interseluler. ${ }^{64}$ Redford dkk menyimpulkan penjelasan hal ini kemungkinan bahwa induksi IL-10 dapat berbeda antara masing-masing isolat M.tb, juga tampaknya bahwa sumber seluler IL-10 selama fase infeksi cenderung dinamis dan mungkin bergantung pada stadium infeksi, dan adanya patogen spesifik. Contohnya pada awal infeksi, sumber utama IL-10 adalah sel-sel myeloid seperti makrofag, kemudian sejalan dengan mulai tampaknya respons imun 
adaptif, maka kemudian sel T yang menjadi sumber utama produksi IL-10. Tetapi hingga saat ini masih sangat sedikit yang diketahui mengenai sumber seluler yang spesifik dari IL-10 selama infeksi M.tb sehingga area ini merupakan lahan penelitian yang masih sangat luas terbuka untuk dikerjakan. ${ }^{67}$

Hasil penelitian ini yang tidak menemukan adanya hubungan yang bermakna antara IL-10 dan TB-MDR berbeda dengan temuan peneliti lainnya, sehingga kami mencari sebab kemungkinan teoritis yang melandasi hal ini. Pada penelitian ini, faktor agen penyebab yaitu kuman M.tb yang mengalami mutasi dan menyebabkan TB-MDR tidak kami selidiki berasal dari strain mana. Sedangkan menurut teori bahwa strain kuman terbanyak di wilayah Asia Tenggara selain didominasi oleh strain Beijing juga oleh strain East-African-Indian (EAI). Strain Beijing telah diketahui memiliki virulensi yang tinggi dan akan meningkatkan produksi IL-10.66 Sementara sepanjang penelusuran kepustakaan yang kami lakukan bahwa penelitian mengenai imunogenisitas strain EAI belum pernah dilaporkan.

\section{KESIMPULAN}

1. Kadar IL-10 pada pasien TB-MDR tidak meningkat

2. Tidak terdapat hubungan antara waktu sejak pertama menderita TB sampai menjadi TB-MDR dan kadar IL10 (nilai signifikansi $>0,05$ )

3. Tidak terdapat hubungan antara riwayat pengobatan pasien TB-MDR dan kategori IL-10 (nilai signifikansi $>0,05$ )

4. Meskipun secara deskriptif terlihat kadar IL-10 pada TB non-MDR lebih tinggi dibandingkan kadar IL-10 pada TB-MDR namun secara statistik tidak terdapat perbedaan yang bermakna (tingkat signifikansi > $0,05)$

5. Tidak terdapat hubungan antara kadar IL-10 dan TBMDR maupun kadar IL-10 dengan TB non-MDR (tingkat signifikansi >0,05)

\section{DAFTAR PUSTAKA}

1. WHO. Global Tuberculosis Report. ; 2012.

2. Yew WW, Chau CH. Drug-resistant tuberculosis in 1990s. Eur Respir J. 1995; 8: p. 1184-92.

3. Depkes R. Pedoman nasional pengendalian tuberkulosis Jakarta: Direktorat Jendral Pengendalian Penyakit dan Penyehatan Lingkungan Kementrian Kesehatan Republik Indonesia; 2011.

4. Eum S, Jeon B, Min J, Kim S, Cho S, Park S, et al. Tumor Necrosis Factor-Alpha and Interleukin-10 in whole blood is associated with disease progression in pulmonary multidrug-resistant tuberculosis. Respiration. 2008; 76: p. 331-7.

5. Crevel RV, Ottenhoff T, Meer JVd. Innate immunity to Mycobacterium tuberculosis. Clin Microbiol Rev. 2002; 15: p. 294-309.

6. Nachega J, Chaisson R. Tuberculosis drug resistance: a global threat. Clin Infect Dis. 2003; 36(Suppl 1): p. S24-30.

7. Thakker $\mathrm{H}$, Shah J. Multi-drug resistant pulmonary tuberculosis. Ind J Tub. 1998; 45: p. 131-9.
8. Pinto L, Menzies D. Treatment of drug-resistant tuberkulosis. Infection and Drug Resistance. 2011; 4: p. 129-35.

9. Catagay T, Kiran B, Yurt S, Gulbaran Z, Kosar F, Catagay P. Level of tumor necrosis factor-alpha and IL-1alpha in newly diagnosed and multidrug resistant tuberculosis. Respirology. 2005; 10: p. 290-4.

10. Geffner L, Yokobori N, Basille J, Schierloh P, Balboa L. Patients with multi-drug resistant tuberculosis display impaired Th1 responses and enhanced regulatory T-cell levels in response to an outbreak of multi-drug resistant tuberculosis $\mathrm{M}$ and Ra strains. Infect immun. 2009; 77 (11): p. 5025-34.

11. Skolimowska K, Rangaka M, Meintjes G, Pepper D, Seldon R, Matthews K, et al. Altered ratio of IFN-gamma/lL-10 in patients with drug resistant Mycobacterium tuberculosis and HIV-tuberculosis Immune Reconstitution Inflammatory Syndrome. PLoS ONE. 2012; 7 (10): p. 1-7.

12. O'Leary S, O'Sullivan M, Keane J. IL-10 blocks Phagosome maturation in Mycobacterium tuberculosis-infected human macrophages. Am J Respir Cell Mol Biol. 2011; 45: p. 172-180.

13. Lee J, CH Song JL, Kim H, Park J, Paik T, Kim C, et al. The production of tumor necrosis factor-alpha is decreased in peripheral blood mononuclear cells from multidrug-resistant tuberculosis patients following stimulation with the $30-\mathrm{kDa}$ antigen Mycobacterium tuberculosis. Clin Exp Immunol. 2003; 132: p. 443-9.

14. Hopewell $P$. Tuberculosis and other Mycobacterial disease. In Mason RJ, Broaddus VC, Murray JF, Nadel JA. Murray and Nadel's Textbook of Respiratory Medicine, 4th edition. Philadelphia: Elsevier Saunders; 2005. p. 984.

15. Hasan H. Tuberkulosis paru. In Wibisono MJ, Winariani, Hariadi S, editors. Buku Ajar Ilmu Penyakit Paru. $1^{\text {st }} \mathrm{ed}$. Surabaya: Departemen Ilmu Penyakit Paru FK Unair-RSUD dr. Soetomo; 2010. p. 9.

16. Loeffler AM, editor. Drug-Resistant tuberculosis: a survival guide for clinicians Los Angeles: Francis J.Curry National Tuberculosis Centre, California Department of Public Health; 2008.

17. Pinheiro R, Dalcolmo M. Tuberculosis and multi-drug resistant tuberculosis: immunologic mechanisms and tools for controlling the disease. J Commun Inf Innov Health. 2008; 2 (1): p. 95-101.

18. PDPI. Tuberkulosis. Pedoman Diagnosis dan Penatalaksanaan di Indonesia Jakarta: Perhimpunan Dokter Paru Indonesia; 2011.

19. Raviglione MC, O'Brien RJ. Tuberculosis. In Fauci AS, Braunwald E, Kasper DL, Hauser SL, Longo DL, editors. Harrison's Principles of Internal Medicine. $17^{\text {th }}$ ed. New York: the McGraw-Hill Co; 2008. p. 1006.

20. Khan AE, Kimerling ME. Chemotherapy of tuberculosis. In Schlossberg $D$, editor. Tuberculosis and Mycobacterium other than tuberculosis. $6^{\text {th }}$ ed. Philadhelphia: the McGraw-Hill Co; 2006. p. 77.

21. Dheda K, Schwander S, Zhu B, Zyl-Smit Rv, Zhang Y. The Immunology of tuberculosis: From bench to bedside. Respirology. 2010; 15: p. 433-50.

22. Patel AM, Abrahams EW. Pulmonary tuberculosis. In Ratlegde, Stanford J, Grange JM, editors. The Biology of mycobacteria. London: Harcout Branch Jovanovick,Academic Press; 1989. p. 179-244.

23. Manabe YC, Dannenberg Jr AM. Pathophysiology: basic aspects. In Schlossberg D, editor. Tuberculosis and Non Tuberculosis Mycobacterial infection. $5^{\text {th }}$ ed.: McGraw Hill; 2006. p. 18-51.

24. Raja A. Immunology of tuberculosis. Indian J Med Res. 2004; 120 : p. 213-32.

25. Bezuidenhout J, Scheider JW. Pathology and pathogenesis of tuberculosis. In Schaaf HS, Zumla A, editors. Tuberculosis a comprehensive clinical reference.: Elsevier Saunders; 2009. p. 120.

26. Zainullah A. Immunopathogenesis of TB: "how to apply in improving of TB treatment?" In Maranatha D, Soedarsono , Hasan $H$, editors. Simposium Nasional TB Up-date IV, Fighting TB: protect the vulnerable population from TB,TB/HIV,and MDR TB; 2007; Surabaya: Departemen IImu Penyakit Paru FK Unair-RSU dr. Soetomo. p. 51-61.

27. Ahmad S. Pathogenesis, immunology, and diagnosis of latent Mycobacterium tuberculosis infection. Clin Dev Immun. 2011;: p. 1-17.

28. Schwander S, Ellner J. Human immune response to M. tuberculosis. In Davies P, Barnes P, Gordon S, editors. Clinical tuberculosis. $4^{\text {th }}$ ed. London: Hodder Arnold an Hachette UK Company; 2008. p. 121. 
29. Mertaniasih N, RJ S, Wahyunitisari M. Patogenesis tuberkulosis. In Mertaniasih N, Koendhori E, Kusumanigrum D, editors. Buku Ajar Tuberkulosis Diagnostik Mikrobiologis. 1st ed. Surabaya: LP3 UNAIR dan Pusat Penerbitan dan Percetakan UNAIR; 2013. p. 35-60.

30. van Crevel R, Ottenhoff T, van der Meer J. Innate immunity to Mycobacterium tuberculosis. Clin Microbiol Rev. 2002; 15: p. 294-309.

31. Abbas A, Lichtman A, Pillai S. Immunity to microbes. In Cellular and Molecular Immunology. $7^{\text {th }}$ ed. Philadelphia: Elsevier Saunders; 2012. p. 350

32. Abbas A, Lichtman A, Pillai S. Effector mechanisms of CellMediated Immunity. In Cellular and Molecular Immunology. $7^{\text {th }}$ ed. Philadelphia: Elsevier Saunders; 2012. p. 225.

34. Dachlan Y. Imunologi Tuberkulosis: sistem imun, pembentukan granuloma, dormansi, reaktivasi infeksi latent, MDR-tuberkulosisi. In The Problems of MDR TB from basic to clinic and community. Surabaya; 2012. p. 4-14.

35. Mitchison D. Drug resistant tuberculosis. Eur Respir J. 2005; 25: p. 376-9.

36. Snider DJR. Infection and disease among contacts of tuberculosis cases with drug-resistant and drug-susceptible bacilli. Am Rev Respir Dis. 1985; 132: p. 125-132.

37. Valway SE. Multidrug-resistant tuberculosis in the New York State prison system, 1990-1991. J Infect Dis. 1994; 170: p. 151-6.

38. Delves P, Martin S, Burton D, Roitt I. Fundamental of immunology: knowing when to make an immune response. In Roitt's Essentials Immunology. 12th ed. United Kingdom: Wiley-Blackwell publishing; 2011. p. 4-6.

39. Cavalcanti Y, Brelaz M, Neves J, Ferras J, Pereira V. Role of TNFAlpha, IFN-gamma, and IL-10 in the development of pulmonary tuberculosis. Pulmonary Medicine. 2012;: p. 1-10.

40. Williams A. Cytokines. In Immunology Mucosal and Body Surface Defences. United Kingdom: Wiley-Blackwell; 2012. p. 68-92.

41. Fiorentino D, MW B, Mosmann T. Two types of mouse $T$ helper cell. Th2 clones secrete a factor that inhibits cytokines production by Th1 clones. J Exp Med. 1989; 170: p. 2081-95

42. D'andrea A, Aste-Amezaga M, Valiante N. Interleukin-10 (IL10) inhibits human lymphocyte interferon gamma production by supressing Natural Killer Cell stimulatory factor/LL-12 synthesis in acessory cells. J Exp. Med. 1993; 178: p. 1041-8.

43. Couper K, Blount D, Riley E. IL-10: the master regulator of immunity to infection. J Immunol. 2008; 180: p. 5771-7.

44. Jacobs M, Bronw N, Allie N. Increase resistance to Mycobacterial infection in the absence of interleukin-10. Immunology. 2000; 100: p. 494-501.

45. Beamer G, Flaherty D, Assogba B, Stromberg P, Gonzales-Juarrero M, Waal-Malefyt Rd, et al. Interleukin-10 promotes Mycobacterium tuberculosis disease progression in CBA/J mice. J Immunol. 2008; 181: p. 5545-50.

46. Deveci $F$, Akbulut $H$, Turgut T. Changes in serum cytokine levels in active tuberculosis with treatment. Mediators of inflammation. 2005; 5: p. 256-62.

47. Zhang M, Gong J, Presky D. Expression of the IL-12 receptor B1 dan B2 subunits in human tuberculosis. J Immunol. 1999; 162: p. 2441-7.

48. Verbon A, Juffermans N, van Deventer S. Serum concentration of cytokines in patients with active tuberculosis and after treatment. Clin Exp Immunol. 1999; 115: p. 110-3.

49. Lago P, Boechat N, Migueis D, Almeida A, Lazzarini L, Zaldanha M, et al. Interleukin-10 and interferon-gamma pattern during tuberculosis treatment: possible association with recurrence. Int J Tuberc Lung Dis. 2012; 16 (5): p. 656-9.

50. biolegend.com. [Online]. [cited 2014 February 15. Available from: www.biolegend.com.
51. Dahlan M. Besar sampel dan cara pengambilan sampel dalam penelitian kedokteran dan kesehatan Jakarta: Salemba Medika; 2010.

52. Yamasaki N, Ozasa K, Yamada, Otsuga, Shimouchi. Gender difference in delays to diagnosis and health care seeking behavior in rural area of Nepal. Int J Tuberc Lung Dis. 2001; 54 (1): p. 24-31.

53. Chiacchio $T$, Cassetti $R$, Butera $O$. Characterization of regulatory $T$ cells identified as CD4 (+) CD25 (high) CD39(+) in patients with active tuberculosis. Clin Exp Immunol. 2009; 156: p. 463-70.

54. Sahiratmadja E, Alisjahbana B, de Boer T. Dynamic changes in pro- and anti-inflammatory cytokine profiles and gamma interferon signaling integrity correlate with tuberculosis disease activity and responsse to curative treatment. Infect Immun. 2007; 75 (2): p. 820-9.

55. Stead W. Pathogenesis of a first episode of chronic pulmonary tuberculosis in man: recrudescence of residual of the primary infection or exogenous reinfection? Am Rev Respir Dis. 1967; 95: p. 729-45.

56. van Rie A, Victor T, Richardson M. Reinfection and mixed infection cause changing Mycobacterium tuberculosis drug-resistant patterns. Am J Respir Crit Care Med. 2005; 172: p. 636-42.

57. Flynn J, Chan J, Triebold K, Dalton D, Stewart T, Bloom B. An essential role for interferon gamma in resistance to Mycobacterium tuberculosis infection. J Exp Med. 1993; 178 (6): p. 2249-54.

58. McDyer J, Hackley M, Walsh T, Cook J, Seder R. Patients with multidrug-resistant tuberculosis with low CD4+ T cell counts have impaired Th1 responsses. J Immunol. 1997; 158 (1): p. 492-500.

59. Lee J, Song C, Kim C. Profiles of IFN-gamma and its regulatory cytokines (IL-12,IL-18 and IL-10) in peripheral blood mononuclear cells from patients with multidrug-resistant tuberculosis. Clin Exp Immunol. 2002; 128: p. 516-24.

60. Flynn J, Chan J. Immunology of tuberculosis. Annu Rev Immunol. 2001; 19: p. 93-129.

61. Torres M, Herrera T, Villareal H, Rich E, Sada E. Cytokine profiles for peripheral blood lymphocytes from patients with active pulmonary tuberculosis and healthy household contacts in responsse to 30kilodalton antigen of Mycobacterium tuberculosis. Infect Immun. 1998;: p. 176-80.

62. Eum S, Lee Y, Min J, Kwak H, Hong M, Kong J, et al. Association of antigen-stimulated release of tumor necrosis factor-alpha in whole blood with responsse to chemotherapy in patients with pulmonary multi-drug resistant tuberculosis. Respiration. 2010; 80: p. 275-84.

63. Pinheiro R, Oliveira Wd, Santos Gd, Silva Gd, Silva BdA, Teles R, et al. Different immunosuppressive mechanisms in multi-drug-resistant tuberculosis and non-tuberculous mycobacteria patients. Clin Exp Immunol. 2012; 171: p. 210-9.

64. Lee J, Son H, Song C, Kim H, Park J, Paik T, et al. Dysregulated production of IFN-gamma, IL-12, and IL-10 by peripheral blood mononuclear cells from early active pulmonary and multi-drug resistant tuberculosis patients. J Bacteriol Virol. 2002; 32 (2): p. 211-9.

65. Shekar-Abi M, Miandehi N, Mansoori S, Fayri M, Alibahar M, Amirkhani A, et al. The study of Th1/Th2 cytokines profiles (IL$10, \mathrm{IL}-12, \mathrm{IL}-4$, and IFN-gamma) in PMBCs of patients with multidrug resistent tuberculosis and newly diagnosed drug responssive case. Tanaffos. 2004; 3 (10): p. 25-31.

66. Brudey K, Driscoll J, Rigouts L, Prodinger W, Gori A, Hajoj SA. Mycobacterium tuberculosis complex genetic diversity: mining the fourth international spoligotyping database (SpolDB4) for classification, population genetics and epidemiology. BMC Microbiology. 2006; 6: p. 23.

67. Rocha-Ramirez LM. Mycobacterium tuberculosis lipids regulate cytokines, TLR-2/4 and MHC class II expression in human macrophage. Tuberculosis. 2008; 88: p. 212-20.

68. Redford P, Murray P, O'Garra A. The role of IL-10 in immune regulation during M.tuberculosis infection. Mucosal Immunol. 2011 May; 4 (3): p. 261-70. 